\title{
Characterization and identification of cashmere in goats in northeastern Brazil
}

\author{
Caracterização e identificação de fibras de cashmere em caprinos no \\ nordeste do Brasil
}

\author{
Lia Souza Coelho ${ }^{1 *}$, Elisa Cristina Modesto ${ }^{2}$, Francisco Fernando Ramos de Carvalho ${ }^{3}$, Sabrina Luzia Gregio de Sousa ${ }^{1}$ \\ ${ }^{1}$ Universidade Federal Rural do Rio de Janeiro (UFRRJ), Rio de Janeiro, RJ, Brazil \\ ${ }^{2}$ Universidade Federal do Rio Grande do Sul (UFRGS), Porto Alegre, RS, Brazil \\ ${ }^{3}$ Universidade Federal de Pernambuco (UFPE), Recife, PE, Brazil
}

\begin{abstract}
In Brazil, approximately 8 million goats are used mainly for milk and meat production, and $91 \%$ of this amount is located in the Northeast of the country. However, the use of animals for the production of textile fibers has not yet been carried out. This study is the first record of cashmere in goats born in that region, through morphological and physical characterization of the fiber. Such a discovery was not expected since cashmere is commonly found in animals predominantly living in countries with cold and mild temperatures. The identification of cashmere from animals born in semi-arid climate is of great importance for both the textile industry and also for the Brazilian producers. Five herds of goats of Saanen and Savannah breeds were investigated, totaling 150 animals. Combing during the month of June 2015 (winter) provided the fiber samples. Samples were evaluated using scanning electron microscopy to properly characterize the fiber (to check the absence of medulla, fiber thickness and other physical properties), and software IMAGEJ was used to obtain the mean fiber diameter. The cashmere
\end{abstract}

found for the two breeds had a mean diameter of $11.00 \pm 0.2 \mu \mathrm{m}$ and a $16 \%$ coefficient of variation with characteristics consistent with cashmere according to the Cashmere and Camel Hair Manufacturers Institute.

Keywords: Undercoat. Saanen. Savannah. Cashmere. Fiber.

\section{Resumo}

No Brasil, cerca de 8 milhões de caprinos são usados principalmente para leite e carne, e 91\% deste montante está localizado no nordeste do país. Entretanto, a utilização dos animais para produção de fibras têxteis ainda não é realizada. Neste estudo, foi reconhecido, pela primeira vez, o aparecimento de fibra de cashmere em cabras nascidas na região nordeste, através da caracterização morfológica e física das fibras. Tal descoberta de cashmere pode ser considerada como inesperada, uma vez que geralmente 
ocorre em animais predominantemente encontrados em países com temperaturas amenas e frias. A identificação de cashmere em animais nascidos em clima semi-árido é de grande importância, tanto para a indústria têxtil como para os produtores brasileiros. Cinco rebanhos de cabras das raças Saanen e Savana foram investigados, totalizando 150 animais. As amostras de fibras foram coletadas no período de junho de 2015 (inverno). As amostras foram avaliadas por microscopia eletrônica de varredura para caracterizar adequadamente a fibra (para verificar a ausência de medula, a sua espessura e outras propriedades físicas) e o software ImageJ foi usado para obter o diâmetro médio da fibra. A cashmere encontrada para as duas raças estudadas tinha um diâmetro médio de 11,00 \pm 0,2 $\mu \mathrm{m}$ e coeficiente de variação de $16 \%$, com características consistentes com cashmere de acordo com o Camel Hair Manufacturers Institute.

Palavras-chave: Subpelo. Saanen. Savana. Cashmere. Fibra.

\section{Introduction}

The goat population in Brazil is estimated in 9.780.533 million of animals, distributed on 436 thousands agribusiness establishments (IBGE, 2016; FAO, 2018). Nowadays, Brazil is the 21st world's largest producer of goat goods (FAO, 2018). A flock of around 7 million goats is located in the northeast, mainly in the states of Bahia, Pernambuco, Piauí, Ceará and Paraíba. The States of Pernambuco and Paraíba are responsible for, respectively, $20.7 \%$ and $5.5 \%$ of the total goat population reared in Brazil.

Goat breeding in the northeast is related to the social and economic population's condition (Lopes et al., 2012). In the study area, goats are mainly intended for the production of meat, milk and skin (Costa et al., 2008). The potential for developing the production of cashmere in northeastern Brazil can provide a new way of income for family farming. Although, the existence of a fine fiber down of cashmere in Brazil is still unknown.

The presence of fine fiber down of cashmere in wild Australian goats was first reported by Smith et al., 1973; in turn, southeastern Brazil, was recently reported by Coelho, 2014. The first register of cashmere goats in the Boer breed in South Africa was reported by Couchman (1988), who highlighted the economic importance and viability of cashmere production as a source of additional income for his country.

The cashmere obtained from goats (Capra hircus) is one of the finest and softest fiber produced by animals and is used exclusively in the production of luxurious textile products (McCarthy, 1998). Cashmere fibers have been found in many breeds of goats (Smith et al., 1973; Lanari et al., 2009; Coelho, 2014). Camel Hair Manufacturers Institute (CCMI) consider cashmere a fine fiber down that should not present medulla, has mean maximum diameter of $19 \mu \mathrm{m}$ and may be no more than $3 \%$ (in weight) of the guard fibers having more than $30 \mu \mathrm{m}$, according to the reference method (IWTO-8, 2004).

The physical characteristics of cashmere's fine fibers down have been evaluated by several studies (Vineis et al., 2008; McGregor and Butler, 2008; McGregor, 2014; Iñiguez et al., 2014; Frank et al., 2017) in different countries. The surface morphology of cashmere fiber has been widely described in the technical literature (Wildman, 1961; Wortmann and Arns, 1986; Wortmann et al., 1989, 2003; Knott, 1990; Ross, 2005). The structure of the fine fiber down cashmere has cylindrical rod, cuticle with distant edges, smooth edges and a scale by height of the rod, wrapping around the rod. Scale frequency, cuticle thickness, cortical cell dimensions were affected by nutritional treatment (McGregor and Liu, 2017), however, there are no studies evaluating the quality of the fine fibers of goats born in northeastern Brazil.

In this study, the objective was to register for the first time the appearance of cashmere in goats born in the northeast of Brazil, through morphological and physical characterization of the fine fiber down.

\section{Material and methods}

\section{Animals and localization}

One hundred and fifty, one-year-old female goats, with an initial body weight of $20 \mathrm{~kg}$ were analyzed for the presence of cashmere. Samples of goat fiber from 
the Saanen and Savannah breeds were collected by brushing all areas of the body of the animal. Saanen and Savannah pure breeds were chosen because they were available there. The animals come from breeding farms located northeastern Brazil and they were capable to produce fleece. In the state of Pernambuco, the city of Recife is at $8^{\circ} 3^{\prime} \mathrm{S}, 34^{\circ} 54^{\prime} \mathrm{W}$, at an altitude of $7 \mathrm{~m}$. Recife has a tropical monsoon climate (Köppen-Geiger classification: Am) with a dry season and a heavy monsoon in the rest of year and no cold season (Belda et al., 2014).

In the state of Paraíba, Brazil, samples were collected in the municipalities of Soledad (latitude 07-03'26"S, longitude 36-21'46"W and at an altitude of $523 \mathrm{~m}$ ) and Taperoá (latitude $7^{\circ} 12^{\prime} 28^{\prime \prime} \mathrm{S}$, longitude $36^{\circ} 49^{\prime} 34^{\prime \prime} \mathrm{W}$ and at an altitude of $533 \mathrm{~m})$. Paraíba has a subtropical dry semiarid climate (Köppen-Geiger classification: BS) with low-latitude dry steppes (Belda et al., 2014).

\section{Collection and sample preparation}

All animals were hand-brushed with fine steel bristle brushes in June 2015. The collection technique was approved by CEUA/UFRRJ 23083.010430/2014-76. The samples fine fiber down were stored in plastic bags for future analysis. The samples of fine fiber down were washed with a mild detergent Extran ${ }^{\circledR}$. For analysis in laboratories, the samples were opened and left in a controlled environment for $24 \mathrm{~h}\left(20^{\circ} \mathrm{C}\right.$ and $65 \%$ R.H.), according to ASTM D1776/D1776M (2016). Samples were analyzed for characterization of the thickness of the scale, the frequency of scale and mean fiber diameter, according to ISO 17751-2 (2016) and IWTO- 58 (2000).

\section{Characterization technique}

Three tangled fragments of the fine fiber down were mounted on carbon tape and aluminum STUB. The samples were coated with gold layer $5 \mathrm{~nm}$ thick by Sputter Coater BAL-TEC SCD 050. The morphological characteristics of the fine fiber down of scale regions, cortex and medulla were obtained using Scanning Electron Microscopy (SEM) JEOL JSM-6490LV. It was secondary electrons, $10 \mathrm{kV}$ acceleration and $4.2 \mathrm{~mm}$ working distance for the acquisition of the images. The mean scale frequency (SF, expressed in $/ 100 \mu \mathrm{m}$ ) and scale thickness (ST, expressed in $\mu \mathrm{m}$ ) were analyzed according to ISO 17751-2 (2016). To analyze the characteristic, it was used an SEM FEG JEOL JSM -7500F with secondary electrons, a measured acceleration voltage of $2 \mathrm{kV}$ and 10.2 mm working distance.

The mean fiber diameter was determined with SEM, according to IWTO-58 (2000). In order to measure more fibers in less time, the FIJI software was used with the DiameterJ plugin (Hotaling et al., 2015). The images obtained in the SEM were processed through software (Fiji Is Just) Image J involving image processing and analysis. The images were pre-treated using contrast and sharpness adjustment operations. The scale was calibrated for each of the images and measurements made of the mean fiber diameter (MFD, expressed in $\mu \mathrm{m}$ ).

\section{Statistical analysis}

Descriptive statistics (mean, standard deviation, coefficient of variation, minimum and maximum values) were calculated for the data of mean fiber diameter, mean scale frequency, scale thickness according to SAS software 9.2 procedures (SAS Institute Inc., Cary, NC).

\section{Results and discussion}

\section{Scale Pattern}

SEM shows cross-section of the thin fiber down (Figure 1). The inner region, corresponding to the cortex region of the fiber, has no medullary structure along the entire fiber stem. This characteristic is important for the softness characteristic and did not differ in fibers of different thickness diameters. In Merino wool-producing sheep, however, the medulla could appear depending on the diameter of the fiber (McGregor et al., 2013).

The fine fiber scales below have a standard morphological characteristic with imbricated transverse position, with a scale at each height of the stem, known as coronal (Figure 2). 


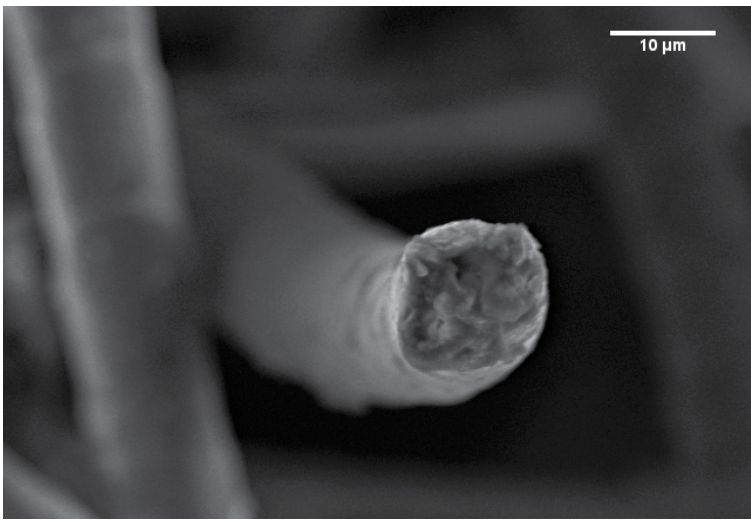

Figure 1 -Scanning Electron Microscopy micrograph (magnification $1800 \mathrm{X}$ ) of the cross-section of fine fiber down of goats in northeastern Brazil, showing the absence of medullary region.

\section{Fiber Diameter}

The mean fiber diameter (MFD) found for both breeds was $10.65 \mu \mathrm{m} \pm 0.24$. Individual values of 7.7-14.1 $\mu \mathrm{m}$ for Saanen goats $11.26 \mu \mathrm{m} \pm 0.26$ and individual values 8.22-16.5 $\mu \mathrm{m}$ for Savannah goats (Table 1).

The results are in accordance to the Cashmere and Camel Hair Manufacturers Institute (CCMI)

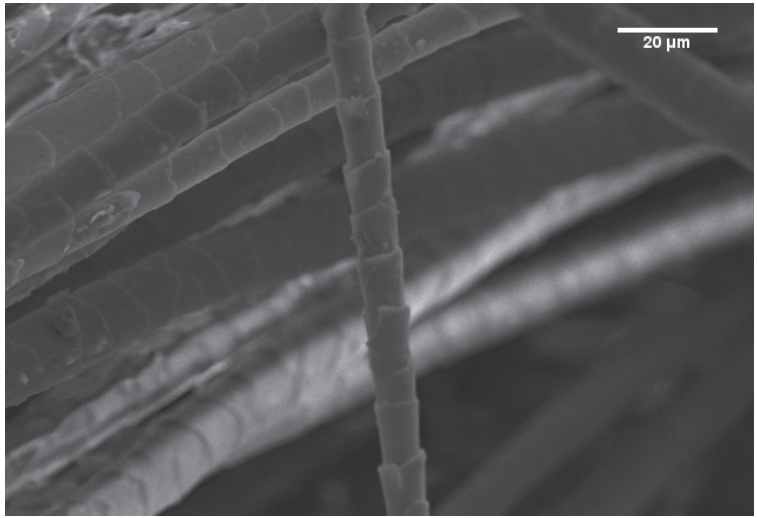

Figure 2 - Scanning Electron Microscopy micrograph (magnification $850 \mathrm{X}$ ) of the morphological structure of the scale of fine fiber down of goats in northeastern Brazil.

to be considered cashmere. MFD of goats studied is thinner than cashmere fiber found in goats in the provinces of Osh, $15.7 \mu \mathrm{m}$, Naryn, $16.7 \mu \mathrm{m}$, in Kyrgyzstan (McGregor et al., 2009) and the regions of Kazakhstan, Kyrgyzstan and Uzbekistan with values in the range of 13.2-26.2 $\mu \mathrm{m}$ (Iñiguez et al., 2014). The CV\% of MFD was $15.83 \%$ and $16.13 \%$ for Saanen and Savannah, respectively, showing good accuracy in the analyzed data (Table 1).

Table 1 - Mean ( \pm standard error), standard deviation (SD), coefficient of variation (CV), minimum (Min) and maximum (Max) of fine fiber down characteristics: MFD (mean fiber diameter), SF (scale frequency), ST (scale thickness), produced by goats in northeastern Brazil.

\begin{tabular}{cccccccc}
\hline Goat fiber & Traits & $\mathrm{n}$ & Mean & SD & CV $(\%)$ & Min & Max \\
\hline Saanen & MFD $(\mu \mathrm{m})$ & 50 & $10.65 \pm 0.24$ & 1.69 & 15.83 & 7.7 & 14.1 \\
& SF $(100 \mu \mathrm{m})$ & 50 & $7.65 \pm 0.15$ & 1.07 & 13.97 & 5.88 & 9.9 \\
& ST $(\mu \mathrm{m})$ & 50 & $0.40 \pm 0.01$ & 0.05 & 11.81 & 0.26 & 0.47 \\
\hline \multirow{2}{*}{ Savannah } & MFD $(\mu \mathrm{m})$ & 100 & $11.26 \pm 0.26$ & 1.82 & 16.13 & 8.22 & 16.5 \\
& SF $(100 \mu \mathrm{m})$ & 100 & $7.28 \pm 0.19$ & 1.33 & 18.28 & 5.15 & 11.7 \\
& ST $(\mu \mathrm{m})$ & 100 & $0.38 \pm 0.01$ & 0.06 & 14.73 & 0.26 & 0.47 \\
\hline
\end{tabular}

Note: $\mathrm{n}=$ number of goats.

\section{Scale Frequency}

The scale frequency is an important parameter to characterize the animal fiber and influence some yarn properties, such as friction and felting (Harizi et al., 2014) and fiber strength (Phan and Wortmann, 1996).
The scale frequency is the number of scales along a shaft of $100 \mu \mathrm{m}$. The scale frequency (SF) was 7.65 \pm 0.15 scales $/ 100 \mu \mathrm{m}$ and $7.28 \pm 0.19$ scales $/ 100$ $\mu \mathrm{m}$ for Saanen and Savannah, respectively (Table 1). The finding is close to that reported by Phan (1991) and Wortmann and Phan (1999). These authors 
observed that thin and thick cashmere fibers have a similar scale frequency of 6-7 scales/100 $\mu \mathrm{m}$. Vineis et al. (2008) evaluated cashmere of $13.9 \mu \mathrm{m}$ mean diameter and found a mean frequency of 6-7 scales $/ 100 \mu \mathrm{m}$, differing from Mohair fiber, which presented scale frequency at $5 / 100 \mu \mathrm{m}$ and fine wool, which, according to Knott (1990), is between 10-12 scales/100 $\mu \mathrm{m}$. According to McGregor and Peña (2017), for each $1 \mu \mathrm{m}$ increase in MFD, cuticle scale frequency declined .15/ $100 \mu \mathrm{m}$. However, this was not observed in this work, where the MFD was smaller than the one found in the literature with the frequency of the scale remaining the same as those found in the references.

\section{Scale thickness}

The thickness of the scale is an important parameter to identify animal fibers; however, the measurement depends on a high-resolution scanning electron microscope (Figure 3).

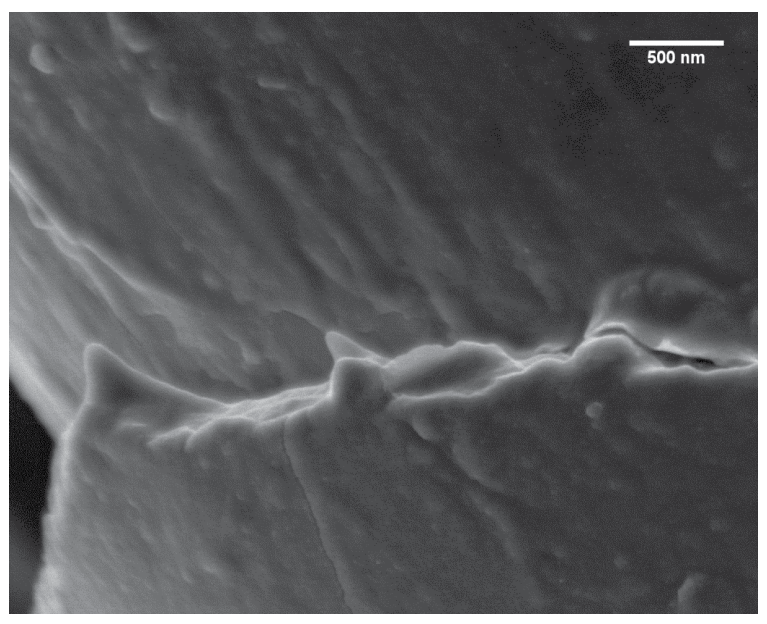

Figure 3 - SEM micrograph (magnification 30000X) of the scale thickness of fine fiber down of goats in northeastern Brazil.

The scale thickness (ST) (or scale height) of goats of the breeds Saanen and Savannah was 0.40 \pm 0.01 and $0.38 \pm 0.01$, respectively (Table 1 ). These results are consistent with IWTO-58 (2000), which uses the thickness of scales to differentiate wool with scale thickness greater than $0.55 \mu \mathrm{m}$ from cashmere with scale thickness of less than $0.55 \mu \mathrm{m}$.
Cashmere scales with a mean diameter of $13.9 \mu \mathrm{m}$ present a thickness of $0.50 \mu \mathrm{m}$ (Vineis et al., 2008).

\section{Conclusion}

Morphological and physical characteristics show that the northeastern goats analyzed here produce high quality cashmere. Therefore, it is important for diversification in the production of goats in Brazil. Furthermore, could promote the formation of the cashmere production chain in Brazil. Through this study, new researches will be promoted for the evaluation of other technical factors related to Brazilian cashmere fibers.

\section{Acknowledgments}

We thank LabNano/CBPF and LME-IQ- UNESP for the electron microscopy facility as well as SENAI CETIQT for its financial support.

\section{References}

American Society for Testing and Materials. ASTM D1776/ D1776M-16 Standard Practice for Conditioning and Testing Textiles. West Conshohocken: ASTM International; 2016.

Belda M, Holtanová E, Halenka T, Kalvová J. Climate classification revisited: From Köppen to Trewartha. Clim Res. 2014;59:1-13.

Coelho LS. Características da capa externa de caprinos em ambiente tropical [master's thesis]. Seropédica: Universidade Federal Rural do Rio de Janeiro; 2014. 80 p.

Costa RG, Almeida CC, Pimenta Filho EC, Holanda Jr EV, Santos NM. Caracterização do sistema de produção caprino e ovino na região semi-árida do estado da Paraíba. Arch Zootec. 2008;57(218):195-205.

Couchman RC. Recognition of cashmere down on the South African boer goat. Small Rumin Res. 1988;1(2):123-6.

FAO. FAOSTAT Agriculture Data [cited 2018 May 29]. Available from: http://www.fao.org/faostat. 
Frank EN, Hick MVH, Russano D, Castillo MF, Prieto A, Aisen EG. Sources of variation in fibre production and quality traits source of variation in down-bearing Patagonian goats and implications for developing a cashmere industry. Small Rumin Res. 2017;150:60-9.

Harizi T, Msahli S, Sakli F, Mekki M, Khorchani T. Surface Morphology Investigation of Tunisian Dromedary Hair. J Agric Sci Technol. 2014;5:454-9.

Hotaling NA, Bharti K, Kriel H, Simon Jr CG. Diameter J: A validated open source nanofiber diameter measurement tool. Biomaterials. 2015;61:327-38.

Instituto Brasileiro de Geografia e Estatística - IBGE. Divisão Municipal - Geociências. 2016 [cited 2017 Apr 6]. Available from: https://tinyurl.com/y8uk8o4l.

Iñiguez L, Mueller JP, Ombayev A, Aryngaziyev S, Ajibekov A, Yusupov S, et al. Characterization of mohair and cashmere in regions of Kazakhstan, Kyrgyzstan and Uzbekistan. Small Rumin Res. 2014;120(2-3):209-18.

International Wool Textile Organisation. IWTO-58: Scanning Electron Microscopic Analysis of Speciality Fibres and Sheep's Wool and their Blends. Ilkley, UK: The Woolmark Company, Techn. Marketing Department; 2000.

International Wool Textile Organisation. IWTO-8: Method of Determining Fibre Diameter Distribution Parameters and Percentage of Medullated Fibres. In: Wool and other Animal Fibres by the Projection Microscope. Ilkley: The Woolmark Company, Techn. Marketing Department; 2004.

International Organization for Standardization. Textiles Quantitative analysis of cashmere, wool, other specialty animal fibers and their blends - Part 2: Scanning electron microscopy method (ISO 17751-2:2016). Brussels: CENCENELEC Management Centre; 2016.

Knott J. Fine animal fibres and their depigmentation process. Guimarães : Universidade do Minho; 1990. 62 p.

Lanari MR, Centeno MP, Arrigo J, Debenedetti S, Abad M. Razas locales y fibras caprinas, bases para un desarrollo rural del norte de la Patagonia Argentina. Anim Genet Resour. 2009;45:55-9.
Lopes FB, Silva MC, Miyagi ES, Fioravanti MCS, Facó 0, Guimarães RF, et al. Spatialization of climate, physical and socioeconomic factors that affect the dairy goat production in Brazil and their impact on animal breeding decisions. Pesq Vet Bras. 2012;32(11):1073-81.

McCarthy BJ. Specialty animal fibres. Textiles. 1998;1:6-8.

McGregor BA. Variation in the softness and fibre curvature of cashmere, alpaca, mohair and other rare animal fibres. J Text Inst. 2014;105(6):597-608.

McGregor BA, Butler KL. Cashmere production and fleece attributes associated with farm of origin, age and sex of goat in Australia. Aust J Exp Agric. 2008;48(8):1090-8.

McGregor BA, Butler KL, Ferguson MB. The relationship of the incidence of medullated fibres to the dimensional properties of mohair over the lifetime of Angora goats. Small Rumin Res. 2013;115(1-3):40-50.

McGregor BA, Kerven C, Toigonbaev S. Sources of variation contributing to production and quality attributes of Kyrgyz cashmere in Osh and Naryn provinces: Implications for industry development. Small Rumin Res. 2009;84(1-3):89-99.

McGregor BA, Liu X. Cuticle and cortical cell morphology and the ellipticity of cashmere are affected by nutrition of goats. J Text Inst. 2017;108(10):1739-46.

McGregor BA, Peña ECQ. Cuticle and cortical cell morphology of alpaca and other rare animal fibres. J Text Inst. 2017;109(6):767-74.

Phan KH. Electron microscopy and the characterization of keratin fibres. Portugal: Guimarães: Universidade do Minho; 1991. 72 p.

Phan KH, Wortmann FJ. Identification and classification of cashmere. European Fine Fibre Network, Occasional Publication No 4; 1996. p. 45-58.

Ross F. Refashioning London tailors; a study of contemporary colour, design and textiles with an evaluation of male consumer sensory perceptions. Proceedings of the 11th International Wool Research Conference; 2005 Sep 4-9; Leeds, West Yorkshire. Leeds: University of Leeds; 2005. 
SAS Institute Inc. SAS/STAT ${ }^{\circledR} 9.2$ User's Guide. Cary, NC: SAS Institute Inc; 2008.

Smith ID, Clarke WH, Turner HN. The potential of feral goats in Australia for cashmere production. J Aust Inst Agric Sci. 1973;39(2):128-31.

Vineis C, Aluigi A, Tonin C. Morphology and thermal behaviour of textile fibres from the hair of domestic and wild goat species. Autex Res J. 2008;8(3):68-71.

Wildman AB. The Identification of Animal Fibres. J Forensic Sci Soc. 1961;1(2):115-9.

Wortmann FJ, Arns W. Quantitative fiber mixture analysis by scanning electron microscopy. Part 1: Blends of mohair and cashmere with sheep's wool. Text Res J. 1986; 56(7):442-6.
Wortmann FJ, Phan KH. Cuticle scale heights of wool and specialty fibers and their changes due to textile processing. Text Res J. 1999;69(2):139-44.

Wortmann FJ, Phan KH, Augustin P. Quantitative fiber mixture analysis by scanning electron microscopy - Part V: Analyzing pure fiber samples and samples with small admixtures according to test method IWT0-58. Text Res J. 2003;73(8):727-32.

Wortmann FJ, Wortmann G, Arns W. Quantitative fiber mixture analysis by scanning electron microscopy Part II: Blends of wool with Angora rabbit hair. Text Res J. 1989;59(2):73-80. 